\title{
Chromatin Immunoprecipitation with Fixed Animal Tissues and Preparation for High-Throughput Sequencing
}

Justin L. Cotney and James P. Noonan

Cold Spring Harb Protoc 2015; 10.1101/pdb.prot084848

The concentration of Tris in the recipe entitled "Cell Lysis Buffer for ChIP-Seq" was incorrect when first published. It should have been $50 \mathrm{~mm}$, not $0 \mathrm{~mm}$. The publisher apologizes for this error. The recipe and the PDF version of the protocol have been corrected. 


\section{Chromatin Immunoprecipitation with Fixed Animal Tissues and Preparation for High-Throughput Sequencing}

Justin L. Cotney and James P. Noonan

Cold Spring Harb Protoc; doi: 10.1101/pdb.err087585

\begin{aligned} & $\begin{array}{r}\text { Email Alerting } \\ \text { Service }\end{array}$ Receive free email alerts when new articles cite this article - click here. \\ & \hline $\begin{array}{r}\text { Subject } \\ \text { Categories }\end{array}$ Browse articles on similar topics from Cold Spring Harbor Protocols. \\ & \hline\end{aligned}

